\title{
The Place of the Republic: Space, Territory and Identity around and after
}

\section{Charlie Hebdo}

\section{Edward Welch}

University of Aberdeen

\section{John Perivolaris}

Independent photographer

\begin{abstract}
Media coverage of the Charlie Hebdo crisis was striking for its triangulation of locations which are emblematic of contemporary France. From the banlieue where the attackers grew up, to the public spaces in central Paris where French national values were reasserted, space and its representation emerged as key perspectives from which to consider the events and what they reveal about the current state of the country. This article examines the spatial dynamics of the crisis, its visual representation, and their role in the framing and consumption of the events. It discusses the work of photographer John Perivolaris, present in Paris in the week following the crisis during a visit planned before the attacks. His images record how popular reaction was inscribed in public space, how memories of previous moments of resistance were reenacted, and how shifting forms of protest are indicative of broader pressures at work on contemporary France.
\end{abstract}

Edward Welch is the Carnegie Chair of French at the University of Aberdeen. His research focuses on the cultural history of post-war France, as it lives through the twin dramas of modernisation and decolonisation. His current work explores the representation of urban space and modernisation in French literary and visual culture. 
His most recent book with Joe McGonagle was Contesting Views: The Visual Economy of France and Algeria, published in 2013 with Liverpool University Press.

edward.welch@abdn.ac.uk

John Perivolaris is an independent documentary and fine art photographer, researcher, writer and curator, with particular interests in migration, refugee experience, diaspora, memory and peripheral urban spaces.

johnperivolaris@icloud.com

\section{Keywords}

Charlie Hebdo, space, territory, identity, terrorism, capital, French Republic

\section{Connections}

Like the attacks on New York in September 2001, the events in Paris in January 2015 were for most people lived and understood through mediation, and visual mediation especially. Rolling television news channels positioned reporters in key locations across Paris as the story of the assault on Charlie Hebdo started to emerge on the morning of Wednesday 7 January. On the morning of Friday 9 January, they carried live pictures of the police pursuit of the Kouachi brothers across Picardy to the village of Dammartin-en-Goële, where they took refuge in a printing factory prior to a final shoot-out that evening. Meanwhile, news anchors began broadcasting from the Place de la République in central Paris, which had emerged on the Wednesday evening as the epicentre of popular reaction to the attacks. The most visible response to the 
attacks, the mass demonstration called by the Socialist government for Sunday 11 January, took on spectacular proportions, and was mediated as such by the state broadcaster: helicopter footage and long shots from elevated cameras captured huge volumes of people moving along the boulevards from the Place de la République to the Place de la Nation. With a reported 1.5 million people joining the march, Le Monde (2015a) amongst other media outlets was soon claiming it as the largest gathering on the streets of Paris since the Liberation in 1944, and estimating that a further 2.5 million people had taken part in similar marches across metropolitan France.

What the television coverage made strikingly clear was the role played by space and location as the events unfolded, and more precisely, by what can be termed the spatial dynamics of the crisis. By this, I mean the way in which the crisis took shape through movement across and between different locations over the five days separating the attack on the Charlie Hebdo and the Republican March, and brought those locations into contact. The motive force of the dynamic was the movement of the terrorists, which drew lines between a series of places in many ways emblematic of contemporary France, from the housing estates of the banlieue to the agroindustrial plains of Picardy and the fringes of the Paris region, with its anonymous industrial units typical of contemporary peri-urban development. Even as the crisis continued to play itself out, with the Kouachi brothers on the run and Amedy Coulibaly holding hostages in the Jewish supermarket at the Porte de Vincennes, popular response to the attacks started to focus on the richly symbolic Place de la République. The square became a locus for the performance of national identity, solidarity and resistance through the resurrection of previous gestures of protest, including the waving of tricolour flags and the climbing of the monument at its centre. 
An investment in symbolic public locations as a way of asserting collective and national identity was confirmed when the Place de la République was made the starting point of the state-organised Republican March on 11 January. ${ }^{1}$

At the same time, while their targets had specific resonance in a French context, the terrorists made explicit reference to horizons beyond France by asserting their allegiance with the international jihadi struggle. It soon emerged that all three had long-standing connections with the transnational networks of radical Islamism. Arrested in 2004 while planning to join the Islamist insurgency in Iraq, Chérif Kouachi was sent to prison in Fleury-Mérogis, where he met Amedy Coulibaly and the radical French-Algerian cleric, Djamel Beghal, who began mentoring them both. Beghal was an associate of Smaïn Ait Ali Belkacem of the GIA (Groupe Islamique Armée), responsible for the bombing of the RER in Paris in 1995 during the Algerian civil war. Kouachi and Coulibaly would be regular visitors to Beghal's house in the Cantal region during 2010, where he was being kept under police surveillance. At least one of the Kouachi brothers (there was uncertainty as to which) travelled to Yemen in 2011, possibly for military training, and in an interview with the commercial news channel BFM-TV during the siege at Dammartin, the pair said they had been commissioned and financed by the branch of Al Qaeda based there (Le Monde, 2015c). Coulibaly claimed allegiance to Islamic State and indicated that he and the Kouachi brothers had co-ordinated their attacks against Charlie Hebdo and the Jewish supermarket, in apparent disregard of the bitter rivalry between their respective sponsors (Byman, 2015). Like many radicalised Muslim men from Western Europe, Coulibaly justified his actions with reference to the Palestinian cause and the suffering of Muslim populations in conflicts prosecuted since 2001 as part of the American-led 'War on Terror' (Le Monde, 2015d; see also Hargreaves, 2015). 
The terrorists' gesture in carrying out the attacks was to bring back home the globalised conflict of terrorism and insurgency, opening up a front of that battle at the heart of their own country; but in doing so as French citizens, they simultaneously raised the question precisely of their own sense of identity, located-ness and attachment to the place of their birth. As Antoine Garapon (2015: 12) suggested, writing in the wake of the events, 'les jeunes tentés par la radicalisation habitent plusieurs espaces mentaux, la France mais aussi le Moyen-Orient; ils sont ici et làbas'. In 'avenging the Prophet', as they declared on leaving the offices of Charlie Hebdo, the Kouachi brothers made clear that their actions were guided by a frame of reference which transcended the earthly laws and traditions of the secular French republic (from this point of view, the fact that an identity card was left behind in the car they crashed as they fled the vicinity of the attack could be read as indicative not so much of rash and careless amateurs, as of a symbolic rupture with their country of birth).

For Garapon (2015: 11), the terrorists' intervention, and the geopolitical allegiances which drove it, are symptomatic of broader processes of 'deterritorialization' at work in the contemporary world, whereby the integrity and stability of the nation state are disrupted by forces which act on its territory, but whose sources lie beyond its purview (transnational terrorist networks would be one example, the global flows of capital associated with neoliberalism would be another). Indeed, if the attacks were lived as profoundly destabilising, both by the government and large sections of the population, and the spontaneous response to them was to gather in nationally significant locations, it was perhaps in part because they were recognised as an indication of the fragility of the domestic order and the country's territorial integrity. In a move which Stuart Elden (2009: xxvii) notes is typical of 
recent work on the threats posed to territorial sovereignty by terrorism, Garapon mobilises the notion of deterritorialization without reference to its origins in the work of Deleuze and Guattari $(1972,1980)$; but as Elden rightly points out, Deleuze and Guattari make clear in Mille plateaux (1980: 634-636) that processes of deterritorialization in turn provoke responses of re-territorialisation which attempt to curb or regulate the lines of flight it opens up: territory is not simply dissolved by deterritorialization, but reconfigured and remapped as a consequence of it.

The aim in what follows is to explore what happened in Paris in January 2015 from the point of view of space and territory. The article argues that mapping the spatial dynamics of the events helps to gain purchase both on the significance of the terrorists' actions in the context of contemporary French society and on the nature of the responses to them, from the appearance of the viral Twitter meme \#JeSuisCharlie on the city's surfaces to the state's co-ordination of popular feeling in its streets on 11 January. In particular, and pursuing the Deleuzian perspective opened up by Garapon in his article, it will consider how the events bring into focus the question precisely of the place of the republic in contemporary France as guarantor of territorial stability and security, and where it is to be found. More specifically, it suggests that the events make manifest on-going pressures on the French nation state in the contemporary moment, and a prolonged crisis of identity of which the attacks and their aftermath were in fact only the latest development.

In exploring these issues, the article engages with the work of urban photographer John Perivolaris, who spent time in the streets of Paris in the week following the crisis, during a visit planned before the attacks. ${ }^{2}$ His images capture the gestures, signs and performances through which responses to the attacks were articulated, and trace the frontier between the event of the protests and the non-events 
of everyday life as they continued around it; but also important was his presence in the city as a photographer. His work invites us to think about how the photographic image helps us grasp the nature of space and the ways in which spaces are inscribed and practiced, not least in the context of an event of national trauma. That is to say, it returns us to the role of visual mediation in shaping the perception, construction and understanding of history.

\section{Aftermath}

Perivolaris arrived in Paris on the evening of Sunday 11 January, as the crowds which had assembled to march between Place de la République and Place de la Nation were beginning to thin and disperse. The images he took in and around République capture the aftermath of the popular demonstrations of outrage, solidarity and resistance which took shape in the square on the evening of 7 January, and were given official form and organisation by the Republican March on the afternoon of 11 January. While a part of the city frequently given over to organised demonstrations, with its wide boulevards and large squares, the particular circumstances of the march meant that the symbolism latent within the route's topography and toponyms could be exploited to the full. Attended by vast numbers of people and led, for its opening few hundred metres at least, by President Hollande and forty or so heads of state from around the world, the march moved between two public spaces whose names could not be more resonant of French national identity and unity. Moreover, it did so down a boulevard named after Voltaire, whose work had resurfaced in the public sphere over the preceding days to stand for France's central role in defining the fundamental principles of freedom of speech and civil liberty. [Figure 1 - République \#7] 
The popular occupation of the Place de la République was striking for a number of reasons. Over the course of its history, it has been an ambiguous and contested space. A key component of Haussmann's strategic urbanism in the nineteenth century, it is dominated by one of the capital's largest garrisons, built to quell the 'classes dangereuses' in the popular quarters of the Right Bank (Hazan, 2002: 176), and has been the site in the past of staged performances of state power (De Gaulle presented the new constitution for the Fifth Republic there in September 1958); but it has also seen spontaneous movements of public protest at various times: most notably, perhaps, the protests of May 1958 during the collapse of the Fourth Republic, or those ten years later during which the future of the Gaullist Fifth Republic was briefly called into question. ${ }^{3}$

The gravitation towards République, which began in the hours after the attack on the Charlie Hebdo offices, was therefore in the spirit of those previous occupations of the square during moments of republican crisis. Likewise, the forms of protest which appeared (flag waving, climbing of the monument at the centre of the square) resurrected and re-enacted archetypal gestures, and their inscription within the mythic tradition of French protest was undoubtedly facilitated by visual representation.

[Figure 2 - Paris After The Killing \#11] Thus, and notwithstanding the different political contexts of the act, the flag waver high up on the monument in the Place de la République could be mistaken for a figure from the Mays of 1958 and 1968; and is indeed a mainstay of iconographies of protest stretching back through France's revolutionary nineteenth century to the Revolution itself.

Similarly, Sunday's march was an event in which the physical occupation of space and movement through it were fundamental to creating its meaning as an expression of collective identity, shared values and commitment to democratic 
principles, not least through the evocation - conscious or otherwise - of previous episodes of mass political expression. ${ }^{4}$ In Perivolaris's images of aftermath, of the detritus left behind after the demonstrations, we can see traces of activity testifying to the population and mobilisation of space, of the passing through of participants drawn to express emotion and affect through their physical presence. [Figure 3 - Paris

After The Killing \#1] Spent matches are material remnants of gestures which are contingent and ephemeral in themselves (the striking of a match to light a candle) but which, through serial repetition, give substance to the event as a collective statement of solidarity and feeling. The lighting of candles, along with the waving of flags, the laying of flowers, or the writing of graffiti are also indications of the importance of gestures as a form of participation. They are inherently performative insofar as the action and its duration in time (the waving of the flag, the burning of the candle flame, the holding aloft of a slogan) are as important as the objects which permit and support it (the flag, the candle, the homemade sign). Taken together, they all contribute to the way in which the event took shape, constituted itself, and gathered memorial form.

Indeed, Perivolaris's images of aftermath in and around the Place de la République raise the broader question of the nature of an event, and how its contours are defined and identified. For the march of 11 January was, in effect, only the last phase of a sequence of actions which had begun the previous Wednesday with the assault on the offices of Charlie Hebdo and which, not least through the performative and symbolic intentions of the march itself, was already gaining historical form as an event, with its narrative shape characterised by a distinctive spatial dynamic in which location, connection and movement through space became especially important. 


\section{Movement}

The event which would end with Sunday's mass mobilisation began with a series of moves round the Paris region by the attackers between the Wednesday morning and the Friday evening of the previous week. In their abruptness and the sense of disorientation they produced, they echoed the definition of the event offered by Slavoj Žižek (2014: 2) as 'something shocking, out of joint, that appears to happen all of a sudden and interrupts the usual flow of things; something that emerges seemingly out of nowhere, without discernable causes, an appearance without solid being at its foundation'. Central to them was the quality distinct to acts of terrorism that spectators and participants have to follow and respond to the moves without being able to anticipate the next one, or the motives behind it.

The particular shock of the terrorist act, arguably, lies in its sudden appropriation of agency and initiative, the power to determine becoming and futurity. It is a power over which the state is used to having control, and which it finds itself struggling to wrest back. The disruptiveness and unpredictability of terrorist agency was manifested most clearly in the flight of the Kouachi brothers after the shootings at Charlie Hebdo, pursued at once by the security forces and by the world's media. Their moves were disconcertingly unreadable. Appearing at first to be making for the Belgian border, they went to ground in a forest near Vémars, before being sighted at a petrol station on the RN2 main road, and heading south back towards Paris. While the pursuit appeared to end by chance at Dammartin, reporters covering the story for rolling news channels, remembering the rocket-propelled grenades the brothers were alleged to have with them, and fuelled by a desire to make sense of their dérive, were quick to point out Dammartin's proximity to the perimeter of Roissy airport, and therefore to one of the modern terrorist's targets of choice, the passenger airliner. 
If the brothers' journey ended on the peri-urban fringe of Paris, it had its starting point both literally and figuratively in other marginal locations, yet ones which have become more powerfully symbolic of the contemporary nation - namely, the deprived housing estates which were the product of France's post-war modernisation, and became home to a large proportion of its populations of immigrant origin during the post-colonial period. The Kouachi brothers, born to Algerian parents, were brought up in an HLM in the $19^{\text {th }}$ arrondissement in Paris, and Chérif Kouachi was living in Gennevilliers, a working-class suburb to the north west of Paris, at the time of the attack. Coulibaly, meanwhile, whose parents were originally from Mali, grew up on the Grande Borne estate in Grigny (Essonne), one of the most iconic grands ensembles of the Trente Glorieuses. Conceived by the architect Émile Aillaud and completed in 1971, the estate comprised a set of low-rise (typically threeto five-storey) apartment blocks with sinuous forms overlooking pedestrianized communal spaces. Its design aimed to combat the problems of isolation and alienation which had emerged with the first wave of grands ensembles, such as Les 4,000 at La Courneuve north of Paris, in the late 1950s and early 1960s. Nevertheless, it did not remain immune from the problems of high youth unemployment, social exclusion and sporadic violence which have been endemic in the French suburbs since the early 1980s, as Coulibaly's own history of delinquency made clear (Bronner and Cazi, 2015).

Reporters from France and elsewhere were soon returning to the banlieue on the trail of the attackers. Keane (2015) offers an example of how the story was framed for television viewers in the UK, indicating a need to locate their origins in a specific place, and thereby give the event its 'discernable causes', to borrow Žižek's phrase. The banlieue emerged as the event's 'solid foundation', helping it to become legible 
and comprehensible. Indeed, it was noticeable how the state itself began to explain what had happened in spatial and territorial terms. A fortnight after the attacks, during his New Year's declaration of good wishes (vœux) to the press, the Prime Minister Manuel Valls, noting what he termed 'la relégation périurbaine' and 'les ghettos', argued that France suffers from 'un apartheid territorial, social, ethnique' (Valls, 2015). While hardly an original claim, having been made repeatedly by a number of commentators since the mid-1980s, it was a telling one in the context: Valls's comment served to re-position the attackers and their motivations within the territory of the French nation, to ground them there at the very moment when their actions and gestures were signalling their rupture with it, and testing the limits of the state's authority over its territory. The need to do so on the part of both the media and the state signalled a sense of anxiety over the status and integrity of French territory after the attacks, which made manifest a force or momentum that had to be contained. In the manner of Deleuze and Guattari's line of flight, this force cut through the structures and formations of the state in reaching towards other places, other battlegrounds and other authorities. Like Hollande's call to assemble in the immediate aftermath of the attacks, Valls's comments, emanating from the locus of state power, were a gesture of re-territorialisation by the state, part of its efforts to frame and contain what had happened by reasserting its purview and agency over the national territory, even if doing so meant articulating that territory as fractured or divided.

To a degree, in other words, January's drama was grounded in the seemingly fundamental, almost ontological opposition in France between centre and periphery, one which is all the more embedded because the economically, socially and culturally marginal occupy, for the most part, geographically peripheral locations. Moreover, a sense of that opposition was certainly accentuated by the gravitational pull exerted on 
large numbers of the population by the symbolically dense spaces of the capital, which developed in direct response to the attackers' movements through and around Paris, but which also produced a reaction of its own amongst those people, often living in the banlieue, who were reluctant to recognise themselves in the proclamation, 'Je suis Charlie'.

Yet the lines drawn between different locations by the movements of the attackers, and different peripheral locations especially - Grigny, Dammartin, the Porte de Vincennes - invite us to consider what is obscured by the straightforward binary opposition of centre and periphery as a way of reading the events. For Gilles Deleuze, 'les lignes sont les éléments constituants des choses et des événements' (1990: 50). By their nature, events are characterised by movement, momentum and becoming. It is through tracing lines drawn and movements made that the causes, significance and consequences of an event become apparent. In particular, the connections made by the attackers' movements produce an effect of triangulation, whereby different locations are brought into relation in a way which maps out and reveals the history of France's socio-economic development in the post-war period; the forces which shaped it and the spaces they produced; and the diverse pressures to which the country finds itself subjected in the present day.

These connected locations, spaces and landscapes bear witness to the complex relationship between modernisation and decolonisation as it plays itself out in postwar urban development, and inequality manifests itself in spatial terms in postcolonial France. They signal how problems of inequality and social exclusion were reinforced following the economic crises of the 1970s and 1980s, when manufacturing plants located in the suburbs and employing large workforces of immigrant origin began to close down as a result of global economic competition. 
They reflect subsequent economic adjustments, with a decline in manufacturing industry bringing a shift towards light and tertiary industry, and a proliferation of warehouses and light industrial units near major road networks accompanying the increased circulation of goods and people as free movement was enshrined in the development of the European Union during the 1990s. At the same time, the nature of the responses which took shape in the capital, as well as the forms they took, were themselves revealing of some of the pressures at work in contemporary France, and could be brought to light by the photographer's presence and movements through the city.

\section{Memes}

One of the most important aspects of the popular response to the attacks was that it was taking place in two locations simultaneously: one physical, the other virtual. On the one hand, there was the physical occupation and practice of space which involved a diverse range of performative statements, including the waving of flags, the lighting of candles and the drawing of graffiti or street art. On the other, there was the viral circulation on social media of the slogan 'Je suis Charlie' coined by Joachim Roncin, artistic director at the French edition of Stylist, a weekly women's magazine, who posted it on Twitter soon after news broke of the attack on Charlie Hebdo. Recirculated 3.4 million times over the following 24 hours, the hashtag \#JeSuisCharlie would become one of the most re-tweeted memes in the company's history (Potet,

\section{5). [Figure 4 - JSC logo]}

Quite noticeably, the Twitter meme soon also started to appear in physical space. Striking too was the fact that it did so predominantly, at least in the first hours after the attacks, in the form of the improvised, spontaneous and interventionist script 
of graffiti. The slogan's material existence and its form both foreground the nature of graffiti as an expression of subjectivity, presence and identity through the physical trace of handwriting. At the same time, the act of inscription intrinsic to graffiti is intended as a claim to ownership of the space. The meme quickly began to proliferate on buildings, pavements and street furniture, including maps and plans of the city.

[Figure 5 - République \#10] The frequency with which these latter were inscribed is particularly suggestive. At one level, they offered prominent and visible surfaces for a spontaneous declaration of solidarity, one bound to catch the eye of passers-by. At another, the gesture of labelling or captioning cartographic representations of the city can also be seen to act out a desire to re-appropriate or reclaim ownership of it by its citizens - even if ownership by and for whom was itself a question lurking within the claim of solidarity and belonging articulated by Roncin's meme, one which would break the surface in different ways as responses to the attacks took shape.

Indeed, it is instructive to consider more closely the origins and fortunes of the 'Je suis Charlie' slogan in this regard. In an interview with Roncin about its birth, the left-of-centre cultural magazine Les Inrockuptibles observed that

Une myriade de références lui traverse l'esprit: le 'Nous sommes tous Américains' publié en une du Monde au lendemain du 11 Septembre, la série des Où est Charlie?, qu'il fait découvrir à son fils de 5 ans, le 'Je suis un Berlinois' prononcé par Kennedy en 1963, auquel il a sûrement pensé inconsciemment. (Boinet, 2015)

Notable (and perhaps surprising) by their absence from this list of possible points of reference are the slogans of May 1968, despite them being arguably the most obvious historical antecedents for creative sloganeering in times of protest. Yet echoes of May 1968 are to be found, and emerge especially when the meme takes on evolved or 
adapted forms: one of the most common was 'on est tous Charlie', with its subtle but significant shift from a singular 'je' to a more broad-based, collective 'on', which is unmistakably a memory of the famous 'nous sommes tous des juifs allemands' uttered in support of Daniel Cohen-Bendit as he faced expulsion from France as a result of his leadership of the student revolt.

Nevertheless, if the Twitter meme is a step removed from the protest slogans of 1968 , it is so not simply because of the new ways in which it circulates, but because of the form it takes. As Roncin makes clear in his interview, it was conceived from the start as a brand or logo as much as a slogan; that is to say, as an object in which visual form is as important as linguistic content: ' $\mathrm{j}$ ' ai pris le logo de Charlie Hebdo pour en faire autre chose. C'est ce que je fais tous les jours: remixer des images, donner une nouvelle vie à des objets en les refaçonnant. J'adore la pop culture, le détournement' (Boinet, 2015). ${ }^{5}$ Roncin created his logo by retaining the typographical form of the first half of the satirical magazine's title, using the house font of his magazine for the phrase 'je suis', and combining them on a jet black background whose connotations of mourning are plain. If the slogan certainly multiplied and morphed in reaching the streets as graffiti, it was in the stable and standardised form of the logo that it became most visible in public space, whether through projection on public buildings in Paris and around the world, or the holding aloft of home-printed copies by those gathered at the Place de la République and other places of protest.

The shift from slogan to logo, and the simultaneous proliferation of that logo in public space, are at once telling and unsurprising. They both reflect broader economic and cultural shifts at work in the contemporary period. Roncin's seemingly instinctive turn to the logo form as a way of articulating his reaction to the events - he 
noted (Roncin, 2015) that he created it because he was 'sans mot' - is an indication of the status and currency of the logo in contemporary culture; but as Naomi Klein (2000) was among the first to remind us, logos are also central to a neoliberal economy of consumption which is predicated on subjective investment in the particular set of 'values' or connotations carried by logos and brands on behalf of the products they identify, rather than the products themselves. That popular response to the attacks became channelled most visibly through the adoption of Roncin's logo was entirely appropriate within a culture geared towards the egocentric consumption and display of signs. ${ }^{6}$

At the same time, those general trends, which signal the growing influence of multinational corporations in a globalised economy, have been felt particularly acutely in contemporary France, as it attempts to negotiate the increasingly tense, not to say unequal, relationship between state power on the one hand, and the power of capital on the other (Waters, 2012). The pressures placed on the country by the power of global capital are expressed in Perivolaris's photograph of an old man on a street corner standing next to a shop front displaying the logos of Adidas and Reebok, international sports goods manufacturers. [Figure 6 - République \#13] The image captures how corporate identity asserts itself in public space, as buildings become platforms for the display of corporate logos and brand identities. Furthermore, those logos are presented in ways clearly intended to enhance their auratic quality. The use of subdued monochrome, with black logos set against a grey background, has the effect of emphasising their formal qualities and thereby, their recognisability and status as icons. ${ }^{7}$ The old man looks strangely out of place against this backdrop. His dress and manner lend him an appearance more familiar from the street photography of Robert Doisneau or Willy Ronis in post-war, working-class Paris. Through his 
embodiment of the past in the corporatized space of the contemporary Parisian street, the image takes on an allegorical quality. It signals the distance travelled by France during the post-war period; its steady but uneven transformation into a post-industrial, consumer society; and its increasing vulnerability to the unpredictable, global flows of capital.

\section{Crisis}

Also present in this image, through the old man's stasis and the quiet of the street, is a sense of being on the fringes of the event, at the point where the energy of the protests rippling out from République has dissolved away into the non-event of daily life. Agency seems to lie elsewhere; and the question of agency and its location is precisely what is raised by the image, and by the events of January 2015 more broadly. The events played out across the spaces and territories of the Republic in January reveal its place to be ambiguous and uncertain. On the one hand, the Republic could not have been more visible, that visibility predicated on the use and occupation of space in order to re-establish Republican order and identity; but its extreme visibility was also a sign of uncertainty, the desire to assert the presence of the Republic an indication of the threat to which it felt exposed. January's events were a crisis of territory, and therefore of national identity; but in many ways, it was a crisis which had already been in play for some time, and whose contours the attacks only served to delineate more clearly. The threat to the integrity of the Republic posed by Islamic extremism is only the latest form of pressure on the contemporary French state from extra-territorial forces, of which the global capital flows associated with neoliberalism are the most obvious and visible. ${ }^{8}$ 
The cultural logic of those forces found form most powerfully in the mass adoption of a slogan whose peculiar contradictions signalled division even as it seemed to assert belonging and solidarity. 'Je suis Charlie' makes a claim which is simultaneously inclusive (I identify with Charlie) and exclusive (I am talking about myself) at its very moment of articulation and which, through its emphasis on the first person singular, can only really point to an aggregation of singularities. Even the 'on' of 'on est tous Charlie' falls short of expressing an explicitly collective identity, a first person plural; and in any case, it was a gesture of identification that large sections of the French population (many of whom were located in the sorts of geographically marginal places familiar to the attackers) were not prepared to make. The events of January 2015 are troubling at once for their uniqueness - their once-in-a-lifetime combination of horror, grief and euphoria - and also because they crystallise so many of the historical, social and economic pressures at work on the country; pressures which the moment of apparent solidarity and resistance they produced ultimately did more to confirm than to defuse. ${ }^{9}$

\section{Notes}

1. The terrorists were also keen to ensure a visual trace of their actions would remain. In the days afterwards, Le Monde (2015b) reported that they had equipped themselves with wearable GoPro video cameras, indicating a clear intention to record and stage their acts as spectacle for posterity. During the sieges at Dammartin and the Porte de Vincennes, both the Kouachi brothers and Amedy Coulibaly had spoken willingly to BFM-TV, one of France's main commercial news channels; and on the morning of 11 January, in a move typical of terrorist groups in the age of social media, two videos in 
which Coulibaly discussed the attacks were published on the websites of YouTube and Dailymotion, before being taken down by the French Interior Ministry.

2. Our collaboration in this article is part of an on-going dialogue on questions of space, movement, identity and urban peripheries in Paris (Perivolaris and Welch, 2014a, 2014b), itself inflected by the coincidence of a long-planned trip to the city by Perivolaris with the aftermath of the attacks.

3. The tension between popular and official occupation of the square was made strikingly manifest on 11 January in the unexpected and cognitively dissonant sight of CRS riot police, so often the most visible and threatening expression of state power during popular protest, being applauded by the assembled public.

4. The ghosts of a number of events could be felt, from the demonstration against the Charonne metro deaths in the last days of the Algerian War in 1962, to the protests of May 1968, including the Gaullists' triumphant march along the Champs Élysées which brought the period to a close. Alongside these are more occulted memories, such as the silent march through Paris by Algerians on the evening of 17 October 1961, which ended in brutal suppression by the police.

5. Roncin's casual reference to the Situationist concept of détournement here, almost as an afterthought, is indicative at once of the presence of May 68 and post-war radical culture in the collective unconscious, and of their absorption as ludic rather than political acts.

6. The fact that Roncin's logo quickly became subject to a struggle over its copyright and commercial usage is equally symptomatic of the latent monetary value it was perceived to have: while Roncin himself refused to seek copyright for the slogan, France's national intellectual property authority, the INPI, declined to accept any of the 120 applications to do so that it received from third parties (Boinet, 2015). 
7. Moreover, the increasing sophistication of corporate brand management is reflected in the playful disruption of the logos: thus, the second ' $a$ ' of Adidas in the brand's classic trefoil logo is transposed below to form the beginnings of the more recent version based on three stripes.

8. Indeed, one of the most striking things about the organisation and structures of contemporary Islamist terrorist movements is how they resemble those of global corporations, for example through the use of a franchising model whereby the name ('brand') of the organisation is adopted by individuals or groups who are inspired by its aims even if they have no direct or formal relationship with it (Francis, 2015). That the desire for symbolic capital through affiliation is as much to do with brand identity as ideological substance is reflected in the fact that the three terrorists could claim to have worked together on their attacks despite the fierce competition between their sponsoring organisations, of which they appeared to have little knowledge or interest. 9. Final revisions were being made to this article when a second wave of terrorist attacks struck Paris on the evening of Friday 13 November 2015. 130 people were killed by gunmen in co-ordinated assaults on locations in the 10th and 11th arrondissements not far from the Place de la République, including bars, restaurants and the Bataclan concert venue. Three terrorists blew themselves up outside the Stade de France in St Denis having tried to get into the stadium, where a football match between France and Germany was being broadcast live on television. Faced once again with a threat to France's sovereign territory, François Hollande quickly declared a state of emergency, tightening security at the country's borders. Meanwhile, Islamic State claimed responsibility for the attacks, and details of a transnational network of terrorist movement emerged, connecting Paris with Belgium and Syria, via the increasingly well-trodden migration route through Greece and the Balkans. Without 
the structuring focal point provided by Charlie Hebdo, and more obviously unsettled by the arbitrary violence of the assaults, public response in the following days was confused and hesitant compared to the previous January.

\section{References}

Boinet C (2015) Qui se cache derrière le slogan 'Je suis Charlie'? Les Inrockuptibles, 22 January. Available at: http://www.lesinrocks.com/2015/01/22/actualite/quise-cache-derriere-le-slogan-je-suis-charlie-11549378/ (accessed 25 August 2015).

Bronner L and Cazi E (2015) Amedy Coulibaly: la fabrique d'un terroriste. Le Monde, 16 January. Available at: http://www.lemonde.fr/policejustice/article/2015/01/15/amedy-coulibaly-la-fabrique-d-un-terroriste (accessed 6 August 2015).

Byman D (2015) Comparing Al Qaeda and ISIS: different goals, different targets. Prepared testimony before the Subcommittee on Counterterrorism and Intelligence of the House Committee on Homeland Security, 29 April. Washington: The Brookings Institution. Available at: http://www.brookings.edu/research/testimony/2015/04/29-terrorism-in-africabyman (accessed 6 August 2015).

Deleuze G (1990) Pourparlers. Paris: Éditions de Minuit.

Deleuze G and Guattari F (1972) L'Anti-CEdipe: capitalisme et schizophrénie, 1. Paris: Éditions de Minuit.

Deleuze G and Guattari F (1980) Mille plateaux: capitalisme et schizophrénie, 2. Paris: Éditions de Minuit. 
Elden S (2009) Terror and Territory: The Spatial Extent of Sovereignty. Minnesota: University of Minnesota Press.

Francis D (2015) Al Qaeda's blueprint for how to start a homegrown terror franchise. Foreign Policy, 20 May. Available at: http://foreignpolicy.com/2015/05/20/al-qaedas-blueprint-for-how-to-start-ahomegrown-terror-franchise/ (accessed 30 August 2015).

Garapon A (2015) Que nous est-il arrivé? Esprit 412: 6-19.

Hargreaves A (2015) French Muslims and the Middle East. Contemporary French Civilization 40(2): 235-254.

Hazan E (2002) L'Invention de Paris: il n'y a pas de pas perdus. Paris: Seuil.

Keane F (2015) Charlie Hebdo attack: the suburbs and the suspects. BBC News, 8 January. Available at: http://www.bbc.co.uk/news/world-europe-30737572 (accessed 18 August 2015).

Klein N (2000) No Logo. London: Flamingo.

Le Monde (2015a) Contre le terrorisme, la plus grande manifestation jamais recensée en France, 12 January. Available at: http://www.lemonde.fr/societe/article/2015/01/11/la-france-dans-la-rue-pourdefendre-la-liberte (accessed 29 October 2015).

Le Monde (2015b) Amedy Coulibaly avait une caméra GoPro pendant la prise d'otages, 11 January. Available at: http://www.lemonde.fr/societe/article/2015/01/11/amedy-coulibaly-avait-unecamera-gopro-pendant-la-prise-d-otages (accessed 5 August 2015).

Le Monde (2015c) Les terroristes avaient revendiqué dès 10 heures leurs attaques sur BFM-TV, 9 January. Available at: 
http://www.lemonde.fr/societe/article/2015/01/09/eux-charlie-hebdo-moi-lespoliciers-le-temoignage-des-terroristes-sur-bfm-tv (accessed 6 August 2015).

Le Monde (2015d) Amedy Coulibaly se justifie auprès de ses otages dans un enregistrement, 10 January. Available at: http://www.lemonde.fr/societe/article/2015/01/10/amedy-coulibaly-se-justifieaupres-de-ses-otages-dans-un-enregistrement (accessed 5 August 2015).

Perivolaris J and Welch E (2014a) Bridges and concrete. In: Carpenter J and Horvath $\mathrm{C}$ (eds) Voices and Images from the Banlieue/Voix et images de la banlieue. Oxford: Banlieue Network, pp. 26-31.

Perivolaris J and Welch E (2014b) Maps, thresholds and beaten tracks: a photographer in the city. Available at: http://www.berfrois.com/2014/10/maps-thresholds-beaten-tracks/ (accessed 6 August 2015).

Potet F (2015) 'Je suis Charlie', c'est lui. Le Monde, 9 January. Available at: http://www.lemonde.fr/m-actu/article/2015/01/09/je-suis-charlie-c-est-lui (accessed 18 August 2015).

Roncin J (2015) Comment j'ai créé 'Je suis Charlie'. Libération, 13 January. Available at: http://www.liberation.fr/societe/2015/01/13/comment-j-ai-creeje-suis-charlie_1180024 (accessed 27 August 2015).

Valls M (2015) Discours de Manuel Valls lors de ses vœux à la presse, 20 January. Available at: http://www.gouvernement.fr/partage/4980-discours-de-manuelvalls-lors-de-ses-voeux-a-la-presse (accessed 18 August 2015).

Waters S (2012) Between Republic and Market: Globalization and Identity in Contemporary France. London: Continuum.

Žižek S (2014) Event. London: Penguin. 